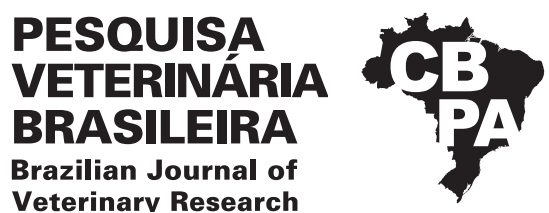

Pesq. Vet. Bras. 40(4):266-270, April 2020 DOI: $10.1590 / 1678-5150-P V B-6210$

Original Article Veterinarv Research

ISSN 0100-736X (Print)

ISSN 1678-5150 (Online)

\title{
Effect of different doses of dexamethasone on labor in Santa Inês ewes and its influence on the onset of labor and the expulsion of fetal membranes ${ }^{1}$
}

\author{
Elisiane S. Santos ${ }^{2}$, Rodrigo F. Bittencourt ${ }^{2 *}$ (D) Antonio L. Ribeiro Filho ${ }^{2}$, \\ Fernanda T.D. Dantas ${ }^{2}$, Álvaro Alves ${ }^{2}$, João V.G.S. Carvalho ${ }^{2}$ and Maria C.C. Ayres ${ }^{3}$
}

\begin{abstract}
Santos E.S., Bittencourt R.F., Ribeiro Filho A.L., Dantas F.T.D, Alves A., Carvalho J.V.G.S. \& Ayres M.C.C. 2020. Effect of different doses of dexamethasone on labor in Santa Inês ewes and its influence on the onset of labor and the expulsion of fetal membranes. Pesquisa Veterinária Brasileira 40(4):266-270. Setor de Reprodução, Universidade Federal da Bahia, Av. Adhemar de Barros, Ondina, Salvador, BA 40170-110, Brazil. E-mail: rfb@ufba.br

The induction of labor aims to concentrate births to follow up better the parturient and the first care to the neonates. However, even if the labor induction technique with dexamethasone administration has been successfully described since the late 1970s, few studies report the technique of birth development and neonatal vitality in Santa Inês sheep. This study aimed to evaluate the efficiency of dexamethasone use in two doses ( 8 and 16mg) in labor induction of Santa Inês ewes at 145 days of gestation and to evaluate its effects on the birth characteristics. In this study, 58 ewes were used, raised in an extensive system in the experimental farms of UFBA, with confirmation pregnancy after fixed-time artificial insemination or controlled breeding. These female ewes were separated into three groups according to the dose of dexamethasone administered (G1 $=0 \mathrm{mg}, \mathrm{G} 2=8 \mathrm{mg}$, and G3 $=16 \mathrm{mg}$ ). From these births, 79 lambs were born. This study analyzed the period from induction of labor to birth, fetal presentation at birth, the weight of the placenta, and the period for placenta expulsion. The data were analyzed by the Statistical Analysis System (SAS v.9.1.3 ${ }^{\circledR}, 2002$ ), and the significance level considered for all analyzes was $5 \%$. Births of induced groups occurred on average at $48.4 \pm 22.17$ hours after induction, while the females with non-induced labor gave birth $131.96 \pm 41.9$ hours on average after the placebo application $(\mathrm{P}<0.05)$, confirming the efficiency of both doses for induction of labor. The period from induction to birth did not differ $(\mathrm{P}>0.05)$ between the doses used. There were no differences in delivery about the fetal static relation, time to placental attachment, and weight. With this study, it can be concluded that the induction at 145 days of gestation with eight or $16 \mathrm{mg}$ of dexamethasone is a useful technique and does not alter the labor in Santa Inês sheep.
\end{abstract}

INDEX TERMS: Dexamethasone, labor, Santa Inês ewe, fetal membranes, sheep, parturient, corticoid, reproduction biotechnology, ewe.

RESUMO.- [Efeito de diferentes doses de dexametasona para a indução do parto em ovelhas Santa Inês e sua influência sobre as características do parto.] A indução do parto visa

\footnotetext{
${ }^{1}$ Received on August 1, 2019.

Accepted for publication on September 16, 2019.

Master's research with support from CAPES.

${ }^{2}$ Setor de Reprodução Animal, Universidade Federal da Bahia (UFBA), Av. Adhemar de Barros s/n, Ondina, Salvador, BA 40170-110, Brazil. *Corresponding author: rfb@ufba.br

${ }^{3}$ Departamento de Anatomia, Patologia e Clínicas Veterinária, Universidade Federal da Bahia (UFBA), Av. Adhemar de Barros s/n, Ondina, Salvador, BA 40170-110, Brazil.
}

concentrar os nascimentos para melhor acompanhamento das parturientes e primeiros cuidados aos neonatos. Contudo, mesmo que a técnica de indução de parto, com administração de dexametasona, tenha sido descrita com sucesso desde o final da década de 70, existem estudos escassos que relatam a influência desta técnica sobre o parto em ovinos da raça Santa Inês. Dessa forma, o objetivo do estudo foi avaliar a eficácia da dexametasona em duas doses (8 e 16mg), para a indução do parto de ovelhas Santa Inês com 145 dias de gestação e avaliar os seus efeitos nas características de desencadeamento e finalização do parto. Para este estudo foram utilizadas 58 ovelhas, criadas em sistema extensivo nas 
fazendas experimentais da UFBA, com prenhez confirmada após inseminação artificial em tempo fixo ou monta controlada. Essas fêmeas foram separadas em três grupos, de acordo com a dose de dexametasona administrada (G1 $=0 \mathrm{mg}$, G2 $=8 \mathrm{mg}$ e G3 $=16 \mathrm{mg}$ ). Destes partos nasceram 79 cordeiros. Foram avaliados o período em horas da indução do parto aos nascimentos, a apresentação fetal ao nascimento, assim como o peso da placenta e o período para o delivramento. Os dados foram analisados pelo pacote estatístico Statistical Analysis System (SAS v.9.0 ${ }^{\circledR}$, 2002) sendo considerado para todas as análises o nível de significância de $5 \%$. Os nascimentos dos grupos induzidos ocorreram em média com 48,4 $\pm 22,1$ horas após a indução, enquanto que as fêmeas com parto não induzido pariram em média 131,96 $\pm 41,9$ horas após aplicação do placebo $(\mathrm{P}<0,05)$, confirmando a eficácia de ambas as doses para indução do parto. 0 período da indução até o parto não diferiu $(P>0,05)$ entre as doses utilizadas. Não ocorreram diferenças no parto em relação à estática fetal, tempo para o delivramento e peso da placenta nos diferentes grupos. Com este estudo, conclui-se que a indução de parto em ovelhas aos 145 dias de gestação com oito e 16 mg de dexametasona é uma técnica eficaz e que não altera o trabalho de parto nas ovelhas da raça Santa Inês.

TERMOS DE INDEXAÇÃO: Dexametasona, indução de parto, parto, ovelhas Santa Inês, ovinos, parturiente, corticoide, biotecnologia da reprodução.

\section{INTRODUCTION}

Among the benefits achieved with labor induction, there is the optimization of labor available on the farm, reduced time in observing the parturient ewes, and assisting females in labor and neonates (Özalp et al. 2017). The technique aims to reduce economic losses by offering assistance to dystocia that occurs in approximately 25\% of sheep deliveries (Dwyer \& Bünger 2012). These actions minimize the mortality of mothers and newborns (Santana et al. 2010).

Among the labor-inducing drugs is the glucocorticoid dexamethasone (Kastelic et al. 1996, Ingoldby \& Jackson 2001). A 16mg dose (Ingoldby \& Jackson 2001) was used from the 137th day of gestation of the sheep, with births occurring approximately 34 to 50 hours after the administration of this corticosteroid (Sir \& Bartlewski 2010).

Exogenous glucocorticoids can induce birth in sheep by mimicking the action of cortisol produced by the fetal adrenal cortex, acting as an initial trigger for a hormonal cascade that triggers birth (Zoller et al. 2015). Corticosteroids still promote fetal maturation, acting mainly on pulmonary maturation (Liggins et al. 1969, Fowden et al. 1995, Ballard et al. 1997, Zaremba, et al. 1997), in addition to activating the maturation of brown adipose tissue, making lambs born with a week less gestation capable of promoting thermoregulation (Bispham et al. 2002).

The labor induction technique with dexamethasone administration has been successfully described since the late 1970s. However, few studies report the influence of this technique on Santa Inês sheep, as well as the efficacy of doses lower levels of dexamethasone for inducing labor and its influence on the onset and completion of labor. In this context, the objective of this study is to evaluate the efficacy of dexamethasone in two doses (8 and 16mg) for the birth induction of Santa Inês ewes at 145 days of gestation and to analyze its effects on delivery (triggering and termination).

\section{MATERIALS AND METHODS}

Experiment location. The experiment was carried out on experimental farms belonging to the Federal University of Bahia, located in the municipalities of Entre Rios and São Gonçalo dos Campos. The farm located in the municipality of Entre Rios is at latitude $11^{\circ} 56^{\prime} 31^{\prime \prime}$ South and longitude $38^{\circ} 05^{\prime} 04^{\prime \prime}$ West, at an altitude of $162 \mathrm{~m}$. It has an average annual rainfall of $1,251 \mathrm{~mm}$ and a hot, semi-humid climate. The farm located in the municipality of São Gonçalo dos Campos is located at latitude 12²5'58' South and longitude $38^{\circ} 58^{\prime} 01^{\prime \prime}$ West, at an altitude of $234 \mathrm{~m}$ and has an average annual rainfall of $1,079 \mathrm{~mm}$ and a hot, semi-humid climate.

Animals and management. The study was carried out according to ethical precepts recommended by the National Council for Animal Experimentation Control (CONCEA), after approval by the Ethics Committee on the Use of Animals (CEUA) of the "Escola de Medicina Veterinária e Zootecnia" of the "Universidade Federal da Bahia" (UFBA), under protocol no. 23/2018.

For this study, 58 sheep were used, 38 sheep from the São Gonçalo farm, and 20 from the Entre Rios farm. The animals were initially submitted to clinical, gynecological, and ultrasound examinations. The transrectal ultrasound was performed with the aid of a multifrequency linear transducer at a $7.5 \mathrm{MHz}$ frequency (Mindray Z5, Shenzhen, China). Clinically healthy females were considered able to participate in the experiment, which at the time of the evaluation did not present any abnormalities in the reproductive tract and absence of pregnancy.

The females were subjected to extensive breeding, maintained on pasture (mixed pasture) with water and mineral salt ad libitum. Before the experiment started, all animals were vaccinated against clostridiosis and dewormed.

Estrus synchronization protocol and return to heat. After the ultrasound evaluation, the animals were submitted to a protocol of estrus synchronization and ovulation in October 2016, in both experimental farms. Initially, on a random day of the estrous cycle (Day 0), all animals received an intravaginal device with $0.33 \mathrm{~g}$ of progesterone (CIDR ${ }^{\circledR}$, Pfizer, Guarulhos, Brazil) with which they remained for eight consecutive days. The intramuscular (IM) administration of 300IU of equine chorionic gonadotropin (eCG, Novormon $^{\circledR}$, MSD Animal Health, São Paulo, Brazil), and $0.125 \mathrm{mg}$ of sodium cloprostenol (PGF2 $\alpha$, Ciosin ${ }^{\circledR}$, MSD Animal Animal, São Paulo, Brazil) was performed on the eve of the removal of the devices. On the ninth day, 200IU of human chorionic gonadotrophin (hCG, Chorulon ${ }^{\circledR}$, MSD Animal Health, São Paulo, Brazil) was applied via IM, 32 hours after the removal of the CIDR. Laparoscopic intrauterine inseminations were performed, with frozen semen from a breeding center, on the tenth day (approximately 56 hours after removal of the intravaginal device). The parameters were above those recommended by the Brazilian College of Animal Reproduction (CBRA) (Henry \& Neves 2013).

From the 14th to the 18th day after the fixed-time artificial insemination (TAI) protocol, the return to estrus of the registered sheep was observed, and a Santa Inês breeder covered the females that presented estrus. The date of the payment was duly registered. Before the beginning of the reproductive program, the male underwent a clinical and andrological evaluation, when it was confirmed that the ejaculation was within the standards recommended by CBRA. 
After 30 days of TAI or coverage, the sheep were evaluated by ultrasound examination to confirm pregnancy with a multifrequency linear transducer (7.5 MHz, Mindray Z5, Shenzhen, China).

Labor induction. At 145 days after coverage or insemination, all females with confirmed pregnancy at 30 days were reassessed for body condition, mammary gland, absence of reproductive diseases, and systemic diseases. Also, to transrectal ultrasound examination, with a multifrequency linear transducer (7.5 MHz, Mindray Z5, Shenzhen, China), for obstetric and fetal viability assessment. The sheep included in the labor induction group had a body condition between 2.5 and 3.5 (Jefferies 1961), were healthy and with pregnancy compatible with the gestational period.

Right after the evaluations, during the period of induction of birth, the sheep were kept in closed facilities, equipped with drinking fountains and troughs, with water, hay, and mineral salt ad libitum, to facilitate the division of groups, observation, and assistance to parturients and neonates.

The females were divided into three groups under a completely randomized design (CRD). At 145 days of pregnancy, the G1 group of sheep (control) received $0.9 \% \mathrm{NaCl}$ solution intramuscularly ( $\mathrm{n}=19)$. G2 ( $n=20)$ was administered 8mg of dexamethasone (Azium ${ }^{\circledR}$, MSD) and G3 $(n=19)$ received $16 \mathrm{mg}$ of dexamethasone (Azium ${ }^{\circledR}$, MSD). From 24 hours after the administration of dexamethasone, the animals were monitored continuously until the 11th day after induction. There was no human interference between the expulsion of the fetus and maternal recognition, except when there was dystocic delivery.

Labor evaluation. Labor was assessed in hours, from induction with 8 and 16mg dexamethasone, at 145 days of gestation, until birth (BIT). In the fetal expulsion phase, the static presented by the fetus was observed. The time interval, in minutes, between births and complete expulsion of the placenta (IEP), was also evaluated. Then the placenta had its weight measured on a semi-analytical scale with a capacity of up to $4200 \mathrm{~g}$, fractioned every $0.01 \mathrm{~g}$.

Statistical analysis. For the analysis of the variables, the statistical program Statistical Analysis System (SAS v. 9.1.3 ${ }^{\circledR}, 2002$ ) was used. Data consistency and descriptive analysis (means and standard deviation) of the characteristics of interest to the study were performed using the MEANS Procedure (PROC MEANS). The Kruskal-Wallis test was used to observe differences between groups (G1 = control, G2 = 8mg, and G3 = 16mg dexamethasone) for the variables that did not show normal distribution by the Shapiro-Wilk test (labor induction interval in minutes and placental elimination). The values were adjusted and compared by the Bonferoni test, in case of significant differences in Kruskal. For variables with a normal distribution (placenta weight), analysis of variance (ANOVA) was performed using the "General Linear Model" Procedure (PROC GLM). For the comparison between the groups studied, it was performed the Tukey-Kramer test. For all analyzes, a significance level of 5\% was considered.

\section{RESULTS AND DISCUSSION}

Fifty-eight sheep participated in this study. Of these, 39 underwent dexamethasone-induced labor protocols, and all responded to the induction protocol. The births in the induction groups occurred on average at 147 days of gestation (48.4 \pm 22.1 hours after the application of the drug). In total, 79 lambs were born. There was no effect of the site (Experimental Farms of Entre Rios and São Gonçalo) on the studied parameters ( $\mathrm{P}>0.05)$. Doses of 8 and $16 \mathrm{mg}$ of dexamethasone were effective in inducing labor in Santa Inês ewes at 145 days of gestation. Induction labor groups G2 (8mg) and G3 (16mg) were similar to each other $(\mathrm{P}>0.05)$ and different from the non-induced group G1 (0mg) $(\mathrm{P}<0.05)$ about the time interval, in hours, between the day of the induction and the births (BIT) (Table 1).

The G1 animals gave birth on average at 150 days of gestation (132.0 \pm 41.0 hours after induction of labor, at 145 days of pregnancy), which corresponds to the physiological behavior for the species. Silva et al. (1995) and Machado \& Simplício (1998) found that, for the Santa Inês breed, delivered at 151.66 and 149.80 days of gestation, respectively.

The first delivery of G1 was recorded 63 hours after administration of the placebo (at 145 days of gestation), that is, a sheep, even though it did not belong to the induction groups, had the delivery at 147 days of gestation. The last delivery in this group was recorded at 203 hours after the placebo, at 154 days of gestation. Thus, the animals belonging to G1 had a variation of 7 days from the first to the last birth, which would require the mobilization of a working group to monitor all parturients and newborns for approximately three times the period of the groups that had induced childbirth, burdening this type of service.

The animals in G2 and G3 calved on average at 147 days of gestation (48.4 $\pm 22.1 \mathrm{~h})$, demonstrating that the dexamethasone used in both doses was efficient in inducing and concentrating labor. It was also observed that, under the conditions of this study, the administration of dexamethasone decreased the delivery date considered physiological by an average of 3 days.

The sheep of G2 that were treated with $8 \mathrm{mg}$ of dexamethasone had an interval between the first and the last birth of 75.8 hours. Three ewes calved within 17-19 hours after induction, that is, at 146 days of gestation, 45\% (9/20) of births that occurred in the first 48 hours after induction and 70\% (14/20) of ewes gave birth within 72 hours, and the last delivery in this group took place 93.3 hours after induction. The G3 treated with $16 \mathrm{mg}$ of dexamethasone showed a 39.1 hours interval from the first to the last birth. Three ewes calved in the first 24 hours (146 days of gestation), the other 16 ewes (84.2\%) calved within 25-53 hours after induction. Sixty-three percent $(63 \%, 13 / 19)$ of births took place between 40 and 53 hours, demonstrating that induction of labor with $16 \mathrm{mg}$ dexamethasone concentrates births 24 to 53 hours after

Table 1. Mean values \pm standard deviation of the time between labor induction and induction of births, expulsion and placental weight in Santa Inês ewes undergoing labor induction with dexamethasone at 145 days of gestation

\begin{tabular}{lcccc}
\hline Treatment & $\begin{array}{c}\text { LDD } \\
\text { (day) }\end{array}$ & $\begin{array}{c}\text { BIT } \\
\text { (hours) }\end{array}$ & $\begin{array}{c}\text { Placental } \\
\text { detachment } \\
\text { (min) }\end{array}$ & $\begin{array}{c}\text { Placental } \\
\text { weight (g) }\end{array}$ \\
\hline $\begin{array}{l}\text { G1 (0mg) } \\
\text { N=19 sheep }\end{array}$ & 155 & $131.96 \pm 41.9^{\mathrm{a}}$ & $233.8 \pm 59.0$ & $375.5 \pm 97.4$ \\
G2 (8 mg) & 149 & $54 \mathrm{w} .35 \pm 26.239^{\mathrm{b}}$ & $230.7 \pm 50.9$ & $389.5 \pm 142$ \\
N=20 sheep & & & & \\
G3 (16 mg) & 148 & $40.97 \pm 12.47^{\mathrm{b}}$ & $239.3 \pm 43.8$ & $310.0 \pm 97.4$ \\
N=19 sheep & & & &
\end{tabular}

G1 = Control group, G2 = labor induction with 8mg dexamethasone group, G3 = labor induction with 16mg dexamethasone group, BIT = birth induction time interval in hours, LDD = group's last day of delivery in days; a,b Values followed by distinct lowercase letters in the same column differ from each other by the Kruskal-Wallis test, adjusted by the Bonferoni test $(\mathrm{P}<0.05)$. 
induction, with a higher frequency of births in the last 13 hours of this interval.

The dose used in G3, 16mg dexamethasone per animal, was chosen according to studies carried out previously by Kastelic et al. (1996) and Ingoldby \& Jackson (2001), establishing themselves as the standard dose for induction of labor in sheep (Sir \& Bartlewski 2010). In this sense, the present study also evaluated in G2 whether the administration of half the conventional dose ( $8 \mathrm{mg}$ ) would have the potential to induce labor with the same efficiency. Tsiligianni et al. (2008) were able to induce the birth process with just two $\mathrm{mg}$ and one and a half mg of dexamethasone at 146 days of gestation, which suggests that induction of labor in ewes with advanced gestation, close to the date of physiological birth, may be performed with low doses. However, the same authors observed dystocia in some births, which made it necessary to use obstetric maneuvers. There was also the occurrence of stillbirths and placental retention in a $10 \%$ average among induced groups, which justified the use of dexamethasone. In the present study, it was used a higher dose than that reported by Tsiligianni et al. (2008) in an attempt to avoid occurrences of the problems above.

The mean time intervals between administration of dexamethasone and births in hours were close to those reported by Kastelic et al. (1996), Balios et al. (2008), Santana et al. (2010). They found 51, 59.7, and 49.38 hours, respectively.

Kastelic et al. (1996), when inducing the birth of 53 Suffolk ewes at 140 days of gestation with $16 \mathrm{mg}$ of dexamethasone associated or not with cloprostenol (CLOP), observed mean intervals (hours) between administration and births: 147.4 hours for ewes with uninduced deliveries, 51 hours for dexamethasone-induced deliveries, and 62.6 hours for dexamethasone and CLOP induced animals. These results demonstrated that the use of CLOP (PG synthetic) does not bring benefits to the induction of labor program in sheep. The corpus luteum (CL) of sheep at 90-100 days of gestation is functional and sensitive to prostaglandins. However, luteolysis is not enough to induce abortion (Weems et al. 1992), since, from the second trimester; the placenta becomes competent to secrete progesterone at levels sufficient to maintain pregnancy, even without the presence of CL (Purohit et al. 2012). Corticosteroids such as dexamethasone, flumetazone, betamethasone, or cortisol acetate perform labor induction effectively (Ingoldby \& Jackson 2001, Purohit et al. 2012). Alternatively, by progesterone antagonists such as Aglepristone (Özalp et al. 2017), the latter has a high cost, which limits its use for this purpose.

Santana et al. (2010) also evaluated the use of dexamethasone to induce labor in Santa Inês ewes, at 144 days of gestation, using doses of 16 and $20 \mathrm{mg}$, in addition to a control group. These authors reported intervals until birth (in hours) of 49.0 ( \pm 6.8$), 78.0( \pm 7.2)$ and $122.0( \pm 37.2)$, respectively, without reports of placenta retain or labor dystocia, reinforcing the positive results obtained in previous studies with the dose of $16 \mathrm{mg}$, not differing from the upper dose.

Labor induction with dexamethasone simulates the natural pathway: the glucocorticoid mimics the cortisol produced by the fetal adrenal cortex, acting as the trigger for the hormonal cascade that initiates labor (Silver 1992). Fetal cortisol induces the transformation of placental progesterone (P4) into estrogen (E2), resulting in a reduction in P4 and an increase in E2 levels. Estrogen induces the release of prostaglandins (PGs), mainly PGF $2 \alpha, \mathrm{PGE}_{2}$, and $\mathrm{PGI}_{2}$, from the uterus. These promote luteolysis, increased placental vascular perfusion, myometrial contractions, and relaxation of the cervix and vaginal canal, triggering childbirth (Silver 1992, Jenkin \& Young 2004).

Around 140 days of gestation, there is an increase in fetal cortisol, and important processes modulated by the cortisol released by the fetus occur, which promotes the neonate's maturity, preparing it for post-uterine life (Ingoldby \& Jackson 2001). At 146 days of gestation, there is the peak of fetal cortisol, suggesting that even a small dose of dexamethasone would be enough to reinforce endogenous cortisol and trigger delivery in periods close to this (Tsiligianni et al. 2008), which explains the performance equivalent between G2 and G3.

As for fetal statics, $94.1 \%$ of the animals were born with the physiological fetal statics for the sheep species, and of these, a lamb (1.3\%) was born with a posterior longitudinal presentation, in a twin birth female product belonging to the induction group with $8 \mathrm{mg}$. The others were born with an anterior longitudinal presentation, dorsal position. These findings are under the normality of the species (Dwyer 2008); they demonstrate that dexamethasone-induced labors did not influence fetal statics.

Four sheep presented dystocia (6.9\%). In these cases, the fetal statics of the dystocic births were the anterior longitudinal, dorsal position, and flexed attitude of the carpal joint. All dystocias occurred in uncomplicated deliveries of male products. Therefore $10.25 \%$ of simple deliveries and $10.5 \%$ of males were born in dystocic delivery, with two births in G1 and two in G2. In these deliveries, obstetric interventions were necessary to correct the attitude, and later, forced traction was performed. All products were born alive. Dwyer \& Bünger (2012) observed a higher percentage of dystocia in simple delivery when the product is male. According to Dwyer (2003), male products are twice as prone to dystocia as females, attributing this finding to weight, since neonates from uncomplicated birth and males are the heaviest. The dystocia values of the present study are below the numbers described by Dwyer \& Bünger (2012), who found in 3,252 animals born in uninduced births $25.1 \%$ of dystocia due to an abnormal fetal presentation.

The placental detachment occurred on average 4 hours after birth (234.6 $\pm 51.3 \mathrm{~min})$ and did not differ between groups $(\mathrm{P}>0.05)$. Detachment time was similar to that found by Tsiligianni et al. (2008). Placental weight was the same in both groups $(\mathrm{P}>0.05)$. It is essential to mention that no female in this study had retained placenta, being considered as "retained placenta" the non-delivery of the organ eight hours after delivery (Jainudeen \& Hafez 2004). Previous studies describe that in sheep, induction of labor with dexamethasone rarely promotes retention of the placenta (Rubianes et al. 1991, Kastelic et al. 1996, Ingoldby \& Jackson 2001, Santana et al. 2010).

\section{CONCLUSION}

The use of dexamethasone in labor induction of Santa Inês ewes at 145 days of gestation, with 8 and $16 \mathrm{mg}$ of dexamethasone, was efficient for the concentration and labor induction, without promoting adverse effects concerning expulsion and fetal static, delivery, and placental weight. 
Ackowledgments.- This study was carried out with the support of the "Coordenação de Aperfeiçoamento de Pessoal de Nível Superior" (CAPES), Brazil, Financial Code 001

Conflict of interest statement.- The authors declare that they have no conflict of interest.

\section{REFERENCES}

Balios A.S., Kassim S.M. \& Al-Oramary A.S.R. 2008. Induction of parturition in ewes local breeds and subsequent survival of neonates. Egypt. J. Sheep Goat Sci. 3(2):65-70. <https://dx.doi.org/10.21608/ejsgs.2008.27816>

Ballard P.L., Ning Y., Polk D., Ikegami M. \& Jobe A.H. 1997. Glucocorticoid regulation of surfactant components in immature lambs. Am. J. Physiol. 273(5):1048-1057.<https://dx.doi.org/10.1152/ajplung.1997.273.5.L1048> $<$ PMid:9374734>

Bispham J., Budge H., Mostyn A., Dandrea J., Clarke L., Keisler D.H., Symonds M.E. \& Stephenson T. 2002. Ambient temperature, maternal dexamethasone, and postnatal ontogeny of leptin in the neonatal lamb. Pediatric Res. 52(1):85-90.<https://dx.doi.org/10.1203/00006450-200207000-00016> $<$ PMid:12084852>

Dwyer C.M. \& Bünger L. 2012. Factors affecting dystocia and offspring vigour in different sheep genotypes. Prev. Vet. Med. 103(4):257-264. <https:// dx.doi.org/10.1016/j.prevetmed.2011.09.002> <PMid:21958901>

Dwyer C.M. 2003. Behavioural development in the neonatal lamb: effect of maternal and birth-related factors. Theriogenology 59(3/4):1027-1050. <https://dx.doi.org/10.1016/S0093-691X(02)01137-8><PMid:12517402>

Dwyer C.M. 2008. Individual variation in the expression of maternal behaviour: a review of the neuroendocrine mechanisms in the sheep. J. Neuroendocr 20(4):526-534. <https://dx.doi.org/10.1111/j.1365-2826.2008.01657.x> $<$ PMid:18266950>

Fowden A., Apatu R. \& Silver M. 1995. The glucogenic capacity of the fetal pig: developmental regulation by cortisol. Exp. Physiol. 80(3):457-467. <https://dx.doi.org/10.1113/expphysiol.1995.sp003860><PMid:7640010>

Henry M. \& Neves J.P. 2013. Manual para Exame Andrológico e Avaliação de Sêmen Animal. 3a ed. Colégio Brasileiro de Reprodução Animal, Belo Horizonte, p.34-37.

Ingoldby L. \& Jackson P. 2001. Induction of parturition in sheep. In Practice 23(4):228-231. <https://dx.doi.org/10.1136/inpract.23.4.228>

Jainudeen M.R. \& Hafez E.S.E. 2004. Gestação, fisiologia pré-natal e parto, p.141-156. In: Hafez E.S.E. \& Hafez B. (Eds), Reprodução Animal. 7aa ed Manole, São Paulo.

Jefferies B.C. 1961. Body condition scoring and its use in management. Tasm. J. Agric. 32:19-21.

Jenkin G. \& Young I.R. 2004. Mechanisms responsible for parturition; the use of experimental models. Anim. Reprod. Sci. 82-83:567-581.< https:// dx.doi.org/10.1016/j.anireprosci.2004.05.010> <PMid:15271480>

Kastelic J.P., Cook R.B., Mcmahon L.R., Mcallister T.A., Mcclelland L.A. \& Cheng K. 1996. Induction of parturition in ewes with dexamethasone or dexamethasone and cloprostenol. Can. Vet.J.37(2):101-102. <https://www. ncbi.nlm.nih.gov/pmc/articles/PMC1576631/pdf/canvetj00099-0039. pdf $><$ PMid:8640645>
Liggins G.C., Rfaircloughs J., Grieves A., Kendall J.Z. \& Knox B.S. 1969. Premature delivery of foetal lambs infused with glucocorticoids. Soc. Endocrinol. 45(4):515-523.<https://dx.doi.org/10.1677/joe.0.0450515> $<$ PMid:5366112>

Machado R. \& Simplício A.A. 1998. Efeito da raça do padreador e da época de monta sobre a eficiência reprodutiva de ovelhas deslanadas acasaladas com reprodutores de raças especializadas para corte. Revta Bras. Zootec. 27(1):54-59. <https://ainfo.cnptia.embrapa.br/digital/bitstream/ item/51069/1/API-Efeito-da-raca.pdf>

Özalp R.G., Yavuz A., Orman A., Seker I., Küçükşen D.U., Rişvanlı A., Demiral Ö.0. \& Wehrend A. 2017. Parturition induction in ewes by a progesterone receptor blocker, aglepristone, and subsequent neonatal survival: Preliminary results. Theriogenology 87:141-147. <https://dx.doi.org/10.1016/j. theriogenology.2016.08.016><PMid:27658744>

Purohit G.N., Shekher C., Kumar P. \& Solanki K. 2012. Induced termination of pregnancy in domestic farm animals. Iranian Journal of Applied Animal Science. 2(1):1-12. <http://ijas.iaurasht.ac.ir/article_513400_ af51c73aa7361fed8d57cc5ad45c05e3.pdf>

Rubianes E., Rodas E., Benech A., Carrau A. \& Ferreira A. 1991. Lambing and placental expulsion time after dexamethasone-induced parturition in Corriedale and Polwarth ewes. Theriogenology 36(2):329-334. <https:// dx.doi.org/10.1016/0093-691X(91)90390-Y> <PMid:16727004>

Santana A.F., Brandão L.S., Sousa F.P., Lima MC. \& Oliveira W. 2010. Indução do parto em ovelhas da raça Santa Inês utilizando diferentes concentrações de dexametasona. PUBVET, Londrina, 4(3):1-9.

Silva F.L.R., Figueiredo E.A.P., Barbieri M.E. \& Simplicio A.A. 1995. Efeito de ambiente e de reprodutor sobre as características de crescimento e de reprodução em ovinos Santa Inês, no Estado do Ceará. Revta Bras. Zootec. 24(4):559-569. <https://ainfo.cnptia.embrapa.br/digital/bitstream/ item/41795/1/API-Efeito-de-ambiente.pdf>

Silver M.1992. Parturition: spontaneous or induced preterm labour and its consequences for the neonate. Anim. Reprod. Sci. 28(1/4):441-449. <https://dx.doi.org/10.1016/0378-4320(92)90131-V>

Sir C. \& Bartlewski P.M. 2010. Analyses of parental and seasonal in $\mathrm{fl}$ uences on the synchrony of dexamethasone-induced lambing and lamb characteristics, Livest. Sci. 131(1):119-124. <https://dx.doi.org/10.1016/j. livsci.2010.03.011>

Tsiligianni T., Ntovolou E. \& Amiridis G.S. 2008. Synchronisation of lambing with low doses of dexamethasone in chios ewes. Acta Vet. Hung. 56(3):393397. <https://dx.doi.org/10.1556/AVet.56.2008.3.12><PMid:18828490>

Weems Y.S., Vincent D.L., Tanaka Y., Miller-Patrick K., Nusser K.D., Ashimine D.T., Ledgerwood K., Lee C.N. \& Weems C.W. 1992. Effect of prostaglandin F2 $\alpha$ (PGF2 $\alpha$ ) on sources of progesterone and pregnancy in intact, ovariectomized and hysterectomized 90-100 day pregnant ewes. Prostaglandins 43(3):203222. <https://dx.doi.org/10.1016/0090-6980(92)90090-G>

Zaremba W., Grunert E. \& Aurich J. 1997. Prophylaxis of respiratory distress syndrome in premature calves by administration of dexamethasone or a prostaglandin F2 alpha analogue to their dams before parturition. Am. J. Vet. Res. 58(4):404-407.<https://www.ncbi.nlm.nih.gov/pubmed/9099388> <PMid:9099388>

Zoller D. K., Vassiliadis P. M., Voigt K., Sauter-louis C. \& Zerbe H. 2015. Two treatment protocols for induction of preterm parturition in ewes - evaluation of the effects on lung maturation and lamb survival. Small Rumin. Res. 124:112-119. <https://dx.doi.org/10.1016/j.smallrumres.2014.12.015> 